\title{
Analysis of the Individualized English Reform Model of Engineering Graduates' English Under the School-Enterprise Joint Mode
}

\author{
Da Liu, Jingwei Shu, Yanfeng Yue, Lin Wang, Nannan Zhang ${ }^{a}$ \\ Department of Foreign Languages, Liaoning University of Science and Technology, Liaoning 114051, China \\ a50017352@qq.com
}

Keywords: Coalition of colleges and enterprises, Graduates, English Reform

\begin{abstract}
With the constant deepening of education reform, China is paying much more attention to education. In the individualized English reform, coalition mode of colleges and enterprises is mainly adopted for engineering graduates, which is beneficial to realize the rational distribution of social resources, and the innovation and development of education. This paper will analyze major modes of postgraduate training under the school enterprise joint mode, and elaborate the current situation of graduate English teaching and personalized reform measures.
\end{abstract}

\section{Introduction}

With the burgeoning of social economy, economic globalization has gradually quickened its pace. Therefore, the demand for English talents is increasing in society. Due to the simplification deficiency in traditional College English teaching, college students' practical ability can be weak even if they are equipped with solid theoretical knowledge [1-2]. Therefore, some colleges and universities adopt school and enterprise joint model to conduct individualized English reform of engineering graduates' English, so as to improve students' oral English competency and practical ability [3].

\section{Major models of graduate training under school and enterprise joint model}

Table 1 Training model for graduates under school and enterprise joint model

\begin{tabular}{ll}
\hline \multirow{2}{*}{ Major training mode } & School \& enterprise “Double Tutorship” system \\
& School \& enterprise project cooperation \\
& School \& enterprise education base \\
\hline
\end{tabular}

\subsection{School \& enterprise "Double Tutorship” system}

In order to achieve the purpose of cultivating engineering master, colleges and universities hire some experienced senior scientific researchers from a professional related enterprise to serve as tutors, who will help to formulate "Double Tutorship" system with school tutors. Two tutors can compensate with each other in the knowledge system and professional skills, so as to make up the practice vacancy of universities in the past. Meanwhile, this mode can provide students with practice opportunities in enterprises, thus strengthening the cultivation of their practical ability.

\subsection{School \& enterprise project cooperation}

School \& enterprise project cooperation means that universities and enterprises work together for a common project, including two kinds of forms: research projects and national scientific research task [4]. Research projects aim to cultivate students through technical cooperation between universities and enterprises, in which case students can continuously sharpen and accumulate experience, thus enhancing the learning ability and level. In national scientific research task, the enterprises and universities jointly undertake the scientific research task while completing the joint 
training task, as shown in Table 2.

Table 2 Cooperation form of school and enterprise project

\begin{tabular}{ll}
\hline \multirow{2}{*}{ Forms of cooperation } & $\begin{array}{l}\text { Research projects } \\
\text { National scientific research task }\end{array}$ \\
\hline
\end{tabular}

\section{Present situation of English Teaching for graduates}

Through the investigation on graduates' English course in three universities, 95\% of the students believe that their courses are different from that of undergraduate students in the way and content of English learning. 85\% of the students hold that English learning should not be simply writing and exercising. What's more, teachers should give more academic knowledge. In recent years, many Polytechnic Colleges and Universities in China divide English course of postgraduates into compulsory and elective courses. The compulsory course includes several basic courses, such as listening, speaking, reading and writing, course of communication, such as Practical Oral English. Elective English course includes academic application type and English skill type courses, which can be presented in table 3. The skill type English also includes oral English, reading, translation and other courses, as shown in Table 4. According to the above findings, English Teaching of engineering graduates should focus on the course of academic English, so as to improve students' academic paper ability and communication ability. The individualized reform of English teaching has become the trend of the times [5].

Table 3 Types of English courses for graduates in colleges and universities

\begin{tabular}{ll}
\hline Curriculum type & Course content \\
\hline Required course & Listening, reading, writing, and practical oral \\
& English \\
Elective course & Academic application type and English skill type \\
\hline
\end{tabular}

Table 4 Skill-based English course

\begin{tabular}{ll}
\hline & English Writing \\
Content & Spoken English \\
& Translation \\
& English reading \\
\hline
\end{tabular}

\section{Improvement measures for engineering graduates' English under school-enterprise joint mode}

Table 5 Improvement measures for engineering graduates’ English

\begin{tabular}{ll}
\hline Improvement & Strengthen communication between two tutors \\
measures & Establish quality assessment system of graduates' English \\
& Reform of teaching evaluation system
\end{tabular}

\subsection{Strengthen communication between two tutors}

The English level and ability of graduates' tutors can exert a direct impact on students. When carrying out the individualized reform of English, schools shall hire a number of enterprise mentors with strong education skills and practical experience. The enterprise requires a number of high level and high quality talents who are familiar with the business process of enterprises. Meanwhile, the college students also want to be provided with opportunities to improve practical skills. The integration of both sides and the strengthened exchanges and communication between double tutors can not only cultivate the talent training, but also enhance students' English learning ability, thus helping them better complete the project [5-6]. 


\subsection{Establish quality assessment system of graduates’ English}

Table 6 Content of the assessment system

\begin{tabular}{ll} 
Content & Practice content, completion situation, learning \\
& progress \\
& Application ability and learning achievement \\
\hline
\end{tabular}

Under the school enterprise joint mode, engineering graduates should strengthen their acquisition of basic English knowledge, based on which they shall also enrich their practical experience and practical skills. Affected by school nature, these schools are more biased towards the theory of engineering in the course of enrolment. Therefore, these schools should actively integrate enterprise technology in the process of individualized English reform, so as to set up corresponding courses. Moreover, they shall also pay more attention to the English education, establish and improve the quality assessment system of graduates' English in actuality. On the one hand, schools shall integrate the practice into the evaluation system as well as supervise the performance and progress of courses; on the other hand, they shall also strengthen the assessment of graduates' study quality. At the end of each semester, students' English learning achievement and practical application ability shall also be assessed, so as to promote their overall development of the theory and application in English learning.

\subsection{Reform of the teaching evaluation system}

The English teaching in school enterprise joint mode should not be simply confined to the teaching of theory. What' more, schools should renew and improve the English Syllabus of postgraduate students, so as to establish a set of government- oriented teaching evaluation system with the joint participation of schools and enterprises, which can adapt to the future development of students. Through the reform of teaching evaluation system, students' overall quality and English level can be significantly improved. Meanwhile, related scholarships can be set up in enterprises, so as to encourage students to improve their English level, thus optimizing the past teaching mechanism and system.

\section{Conclusions}

In summary, China is now paying much more attention to education. The past English teaching mode has been unable to meet the current needs. As a result, the individualized English reform of engineering graduates' English has become the trend of the times. In the course of specific reform, colleges and universities should actively strengthen communication between two tutors, establish English quality assessment system of graduates and reform teaching evaluation system, so as to enhance students' English learning ability and level, thus achieving healthy development.

\section{Acknowledgements}

This work was supported by 2017 Education and Reform Project of Liaoning University of Science and Technology: The Research of “Internet+Manager” Individualized Teaching Mode of University XJGYB201703;2017 Education and Reform Project of Liaoning University of Science and Technology: The Situation and Strategy of the Cultural Issues of English Cross-cultural Course under the International Background(XJGYB201748); The Education Research Project of the Postgraduate Students of National Engineering Majors Degree: Information-based Teaching and the Construction of Efficient Classroom of Innovation education for Postgraduate Students(Project code: 2016-ZX-114).

\section{References}

[1] Harris D M. Curriculum Differentiation and Comprehensive School Reform: Challenges in Providing Educational Opportunity. [J]. Educational Policy, 2011, 25(5):844-884. 
[2] Boer D, Anouk S.|van der Werf, Margaretha P C. Effects of the Attributes of Educational Interventions on Students' Academic Performance: A Meta-Analysis. [J]. Review of Educational Research, 2014, 84(4):509-545.

[3] Noble. A study of the congruence of the rankings of selected composition objectives by secondary language arts teachers and by standardized, commercially published tests of composition[J]. Journal of Personality, 1975, 43(43):390-401.

[4] Saavedra A R. The Academic Impact of Enrollment in International Baccalaureate Diploma Programs: A Case Study of Chicago Public Schools. [J]. Teachers College Record, 2011, 116(4):118-119.

[5] D Soskice. Wage Determination: The Changing Role of Institutions in Advanced Industrialized Countries. [J]. Oxford Review of Economic Policy, 1990, 6(4):36-61.

[6] Thoonen E E J, Sleegers P J C, Oort F J, et al. How to Improve Teaching Practices: The Role of Teacher Motivation, Organizational Factors, and Leadership Practices. [J]. Educational Administration Quarterly, 2011, 47(3):496-536. 